\title{
Hijab and Its' Challenge for Changing New Lifestyle of New Muslim Women
}

\author{
Suraya Sintang, ${ }^{1}$ Khadijah Mohd. Hambali@ Khambali, ${ }^{2}$ Mashitah Sabdin, ${ }^{3}$ Nur Saadah Khair ${ }^{4}$
}

\begin{abstract}
Hijab significantly addresses one of the religious practice and religious identity for Muslim women either those who are born Muslim or new Muslim. The new Muslim women adopt new style of identity markers by changing new lifestyle through wearing hijab. It is also a form of new bodily practices and new forms of behaviour that the new Muslim express themselves as an observant and practising Muslim. However, the journey towards changing lifestyle through wearing hijab is not an easy task for new Muslim women as there are some kind of adverse reaction from family, friends and work colleagues. In this article an attempt is made to present the daily life experience of new Muslim women from diverse cultural background who take on hijab not only as a challenge for their religious practice but also as a way for expressing commitment to strengthening their Islamic identity. The method used is qualitative approach through discourse analysis by examining the extract of personal interview with new Muslim women living in majority nonMuslim countries in Britain and America and the majority Muslim country in Malaysia. The study concludes that the new Muslim women across boundaries of nation in any environment they are living at, most likely would come across the similar challenge of life experience when they took hijab as a progression of their religious practice and a permanent announcement to the outside world of the religious identity.
\end{abstract}

Keywords--Hijab, Religious Identity, Religious Practice, New Muslim

\section{INTRODUCTION}

$C^{a}$ ONVERT to Islam commonly renegotiate not just their religious identity but also many aspects of their cultural, social and gender identities. Changes are manifested in very practical and concrete ways, for example in the form of new bodily practices and new forms of behaviour. The changes involve various aspects of identity formation such as changes in national, racial and ethnic identity, the adoption of new styles and language and other identity markers in terms of dress, names and circumcision ${ }^{[1]}$. In the context of dress particularly the changing lifestyle in wearing hijab, it involves the process of transition in the post-conversion period whereby the new Muslim women gradually learn how to adopt a new style of wearing dress in accordance to Islamic law of conduct.

\footnotetext{
${ }^{1}$ Suraya Sintang, Universiti Malaysia Sabah. Email: surayasin12@gmail.com

${ }^{2}$ Khadijah Mohd. Hambali is Assoc. Prof. at Universiti Malaya. Email: ijamh@um.edu.my

${ }^{3}$ Mashitah Sabdin, PhD student at Birmingham University, Department of Philosophy, Theology and Religion. Email: MXS587@student.bham.ac.uk.

${ }^{4}$ Nur Saadah Khair, PhD student at Birmingham University, Department of Philosophy, Theology and Religion, Email: bintukhair2408@gmail.com
}

The change in dress is usually the most visible and obvious change of all, and therefore the one that elicits the strongest reaction from non-Muslim. It is also often associated to be part of the integration process for new Muslim women to be accepted as a member of Muslim community.

This paper deals with the experiences of new Muslim women in facing the challenge from family reactions on their decisions of choosing the new lifestyle of wearing hijab. The research question to be answered is how they do experience wearing hijab as a new form of behaviour that they express themselves as an individual of observant and practicing Muslim as well as expressing commitment to strengthening their Islamic identity. The method used for data collection is qualitative approach through discourse analysis by examining the extract of interview of new Muslim women's experience both in the environment of majority Muslim in Malaysia and majority non-Muslim countries in Britain and America. The rationale behind studying those living in different environments is to look at the similarities and differences of the challenge that they face on the acceptance of non-Muslim family of origin when they choose hijab as a new lifestyle after conversion to Islam. The preliminary study show that besides the challenging circumstances, they still strongly uphold their stands and commitment on wearing hijab as they believe that hijab is a step towards being an observant and practicing Muslim.

\section{The Origin of Hijab}

The most obvious identification of the Muslim woman (Muslima) is certainly the covering of the head and often the whole body with a veil. The first and foremost meaning of the concept hijab is literally a veil or partition, the veil that separates humankind, or the world, from God ${ }^{[2]}$. The term veil and hijab are often used interchangeably, but the hijab has an Islamic significance that distinguishes it from the veil ${ }^{[3]}$. The veil, which is often perceived in the west as a head-covering, does not reveal the intricacies of the practice. The term hijab encompasses women's behaviour/attitude, and studies have found that a vial feature of the hijab is modest behaviour ${ }^{[4]}$. This article will inter-changeable use both veil and hijab which is applicable to the context of discussion.

According to Mohammed al-Buti [5], "Muslim teachers unanimously agreed in every generation that a female should cover all her body, except her hands and face, that is without any make-up, from strangers." Malikiyah and Hanafiyah legal systems make this further distinction: "If the woman's face is naturally beautiful, then she must cover her face for fear of 
being a temptation to men"[6]. Most sources indicate that the use of hijab is derived from the Qur'an, Surah 33: 59:

O Prophet, tell your wives and daughters and the believing women to draw their outer garments around them (when they go out or are among men). That is better in order that they may be known (to be Muslims) and not annoyed/molested....

The covering of the Muslim woman is referred to in the Qur'an, in Surah an-Nur:

And tell the believing women to lower their gaze, and protect their private parts and not to show off their adornment except that which is apparent, and to draw their veils all over juyubibihinna (their bodies, necks and bosoms etc.) and not to reveal their adornment.

The hijab has different names and manifestations depending on time and place of origin ${ }^{[7]}$ and can be thought of as a continuum from least to most covering. The Shayla, popular in the Gulf region, is worn as a loose-fitting headscarf set in place at the shoulder, leaving the neck visible. The al-amira is a two-piece headscarf consisting of a close-fitting scarf covered by another tubelike scarft, leaving the neck covered and only the face showing. The khimar is a long veil that covers the body just above the waist, leaving only the face visible. The chador is a large open fabric held together at the chin to cover the body and leave the face visible, a smaller headscarf can be worn underneath the chador. The niqab covers the entire body, leaving only the eyes visible. The burqa, the most conservative form of the hijab, covers the body in its entirety, including a gauzelike cover over the eyes (Muslim veils) ${ }^{[8]}$. Although the names of hijab are different according to the culture of the people, the main purpose of its application for women wearing hijab is modesty which function as identity of religious marker and religious boundaries between Muslim-non-Muslim relations.

\section{Application of Hijab as Religious Identity and Expression of Observant Muslim}

The application and the extent of covering vary from community to community. Prusher ${ }^{[9]}$ argues that today, reasons for veiling are as varied as the types of covering women wear, from the long robes and colourful scarves in the North African countries to the black-on-black garb of the conservative Gulf states. The purpose on the whole is modesty for both men and women. Modesty rules are open to a wide range of interpretations. Some Muslim women wear full body garments that only expose their eyes. Some cover every part of the body except their face and hands. Some believe only their hair or their cleavage is compulsory to hide, and others do not observe any special dress rules. The modesty as ${ }^{[10]}$, is the result in both sexes being evaluated on the ground of intelligence and skills, rather than appearance and sexuality. The modesty of hijab for women does not only constitute the covering of the body, but general behaviour, manners, speech and appearance in public. Dress is only one facet of the total being. It is therefore, hijab is taken as a symbolic application presenting an understanding of the general status and rights of women in Islam.

Some previous studies show that the application of hijab contributes to various reasons as it based on the responses given from the interviewees ${ }^{[11]},{ }^{[12},{ }^{[13]}$. Among the given reasons are, "to show my religiosity/morality/modesty," "to show others my Muslim identity," "in response to the encouragement from family (e.g. it would be a positive influence in your life), "in response to pressure from family" (e.g. you must wear it), "so that as a woman, I am to gain respect and treatment as Muslim women, treated with esteem/respect and as an equal," "feeling comfortable in mixed sex settings," "to prevent male harassment or sexual advances," "to protect against Western ideas or lifestyle." The given responses show that two most common reasons for wearing the hijab reflected enactment of one's religious duty and the least frequently selected reason was pressure from family. This shows that the choice of wearing hijab has most likely been taken as a religious obligation towards a better Muslim.

The other study also show that the application of wearing hijab is varied according to the choice of religious, social or political motivations. Al-Wazni ${ }^{[14]}$ found out that all participants were very adamant that it be known that their decision to wear the hijab, regardless of age at initiating the practice, was of their own free will. When asked if the decision to wear the hijab was influenced only by religion or if any other social or political factor contributed to their decision to wear it, none reported any political motivations at any point in time. All participants referenced the same verses in the Quran as clear evidence that the hijab was a commandment from Allah, which obliged women to cover their head and bodies. Although all 12 participants stated that their current motivation for wearing the hijab was based only in religion, a number of participants also noted that there was positive social reinforcement for wearing the hijab at an earlier age, before they were able to intellectually grasp the religious scriptures they now understood to obligate women to cover.

The early discussion indicates that the application of hijab by women plays its important role as identity marker for being recognize as an observant and practising Muslim. In fact, it is apparently give the Muslim women a sense of pride in Islam. The Muslim women were happy to be recognized as Muslims and felt beautiful in the eyes of Allah, though others may have thought it as dowdy or plain. This can be shown at these several case studies as interviewed by $\mathrm{Na}^{\text {'ima }}{ }^{[15]}$ :

i) "The hijab is about saying who you are and what you're about, although I didn't see it like that at the time. But now, I really want to have that identity, to show that I am a Muslim as opposed to blending in with this society."

ii) "It is part of me, it is part of my identity, that is who I am. If I took it off nobody would know I am Muslim and I am proud to be Muslim.

iii) "I love wearing it. I know that I am doing the right thing, and it is a progression in my faith, and it did feel wonderful being able to walk out and know that I have got that little bit closer to being the person that I want to be."

iv) "I felt quite nervous putting it on at first. I feel a lot safer now that I am wearing it. I have more self-respect. Now I know where I belong.

In taking on the hijab, a strong commitment has been made which constitutes a permanent announcement to the outside world of the religious identity of the wearer. It also enhanced 
their identity in two specific and complementary ways: i) strengthening the boundary between themselves and nonMuslim; ii) reinforcing their sense of belonging to the wider Muslim community. This can be illustrated in the case of Sarah Joseph who found that wearing hijab made it easier to be accepted into the community ${ }^{[16]}$. As observed by Haddad ${ }^{[17]}$, converts tend to see their identity not as socially and culturally constructed, but as grounded in their original and natural being as a Muslim. This reflects the idea of converts as "reverts", returning to their original nature, and helps explain why many do not necessarily see themselves as having a "new identity" as such.

However, wearing hijab as a new identity has seen by others as a strange identity which is perceived not in line with the modern western culture. Hijab or veiling was argued to be, and generally accepted as a women's oppression that was stipulated by the Quran. Maira ${ }^{[18}$ points out that the image of the hijab as the symbol of oppression and violence against women by the hands of the uncivilized Muslim man became the rallying point not only for American politicians, but for contemporary Western feminists as well. Some feminists interpret the hijab as a form of sexual objectification, suggesting that it is a mechanism for controlling women's sexuality ${ }^{[19]}$ and perpetuating gender boundaries that exclude women from the public sphere ${ }^{[19]}$. Extending such perspectives, Hatem ${ }^{[20]}$ suggested that wearing the hijab may reflect internalization of the view that women are sexual objects and need to be covered to desexualize themselves. Although the hijab has repeatedly been dismissed by feminist efforts as both degrading and subjugating to male dominance, there is new and emerging research about how the hijab may actually work to protect women against negative body image ideals. Mussap's ${ }^{[21]}$ quantitative study surveyed Australian women found that those who follow the Islamic faith and wear hijab were not necessarily any less likely to compare their bodies to the body ideals produced in the media, but that the hijab did offer protection by "buffering against appearancebased public scrutiny (through adoption of traditional clothing) and by insulating her from exposure to Western ideals.

In another study, Ahmed ${ }^{[22]}$ points out that the reclaiming of the Islamic practice of the hijab as a Muslim women's movement of solidarity, and affirming the Islamic religion and identity as liberating and not oppressive, is an emerging trend amongst American Muslims. Haddad ${ }^{[23]}$ studied secondgeneration American Muslim communities and found that Muslim women born and raised in the United States were increasingly engaging in hijab practices as "an iconic symbol of the refusal to be defined by the Western media and war propaganda since 9/11". Haddad concluded, many Muslim women in America have found American feminists to be complicit in imposing their values on "other" women and see the Western images of the hypersexualized and exposed woman to be contradictory to Islamic beliefs and exploitive of women.

Research on Muslim women's perspectives in the United States and other Western countries suggest some perceived positive functions that Muslim women wear the hijab to reflect a Muslim identity, for social reinforcement from friends and family, to gain esteem or respect and a sense of religious duty ${ }^{[24]},{ }^{[25]},{ }^{[26]},{ }^{[27]}$. In order to fulfill those purposes of applying hijab, women send a clear message to the outside world that they do not want to be bothered and don't want to be approached sexually. It is because their bodies were not on display. This endowed their interaction with men with a new level of respect and courtesy. Women were clearly no longer sexual objects -women had to be treated differently. They would like men would no longer observe their movements and watch the way they walked. In other words, the old ways of relating to women's bodies as sexual image were no longer applicable.

As discuss above, the taking on the hijab is a personal choice for the Muslim women who seek to be observant and practising Muslim. It is a religious duty and not an oppression against women in which they are offended to be perceived as a symbol of sexual object for men. Rather, it is a step towards the improvement to develop a new religious identity for Muslim women to comply with Islam's modesty code. In other words, in taking on the hijab a strong commitment has been made, which constitutes a permanent announcement to the outside world of the religious identity of the wearer. The wearers strongly uphold the Islamic teaching on the obligation of wearing hijab as it is regulated both in countries where Islam is a minority religion and in those where it is professed by the majority. Therefore, this study will deal with the challenging circumstances of new Muslim women when they choose hijab as their new lifestyle after conversion to Islam. The challenging experience is not only come from the family's disapproval of their decision of wearing hijab, but also the challenge to make the others understand that the hijab is part of religious obligation according to the Islamic modest code and a step towards being an observant and practising Muslim.

\section{The Challenge of Wearing Hijab within the Reaction from Family and Friends}

Studying the convert's experience on the challenge of wearing hijab leads to the understanding their religious orientation whereby they choose to wear hijab as their personal choice and commitment. The situation is not similar with the born Muslim women who understand the obligation of wearing hijab is simply to be passed on from one generation to the next. Zebiri [28] points out that converts living in a non-Muslim environment may prompt them to form a more consciously Islamic identity as they are pushed to define themselves more clearly in response to questions they are asked about Islam by curious non-Muslims. There are also many ways in which converts may be different from born Muslims.

Obviously, a convert would not have been brought up in a Muslim family, and their ethnic and cultural background would not therefore be associated with Islam. Not being involved with parochial forms of Islam, converts bring a particular emphasis to the universality of Islam; compared to born Muslims, there are in some ways a 'blank slate', Islamically speaking, in that there is a sense in which they need to weigh everything in the balance. Not having been socialized within a Muslim family also means that converts 
will have been more fully exposed to the impact of the dominant culture. In other words, converts cannot run away from the non-Muslim family because the influences of your family are inside you and you've grown up with them ${ }^{[29]}$. It is therefore choosing Islam as a new path of life and the journey towards being a practising Muslim is more challenging compared those who have born as Muslim by parentage. The challenging situation has more obviously been seen when they decide to change their new lifestyle as prescribed by the Islamic modest of conduct.

Hence, the post-conversion period of transition can be considered the most challenging part of life for the new Muslim women. Zebiri ${ }^{[30]}$ in his interviews with new Muslim women in Britain points out that interviewees were asked whether there was anything that they found difficult in their transition to become Muslim, whether in terms of giving up or of implementing new practices and behaviours. The most frequently mentioned difficulties had to do with leaving and adapting to the five daily prayers and acclimatizing to the hijab. As he illustrated the case of his interviewee that three years after her conversion she said that her family still could not decide whether they wanted to speak to her or not, and she had gone from being the adored only daughter in a close-knit extended family to being unable to attend family events (which would generally include non-mahram males such as brothersin-law) as her parents refused to see her in hijab. She found that their role in the family had completely changed. This situation indicates that hijab becomes a social barrier in the different religions affiliation of family relation.

The study done by $\mathrm{Na}^{\prime}{ }^{\prime}{ }^{[31]}{ }^{[31}$ also show similar findings on the difficulties the new Muslim women in Britain face after taking on the hijab. As she points out that the hijab, without doubt, one of the most difficult aspects of Islam. The challenge involve so many things: the way you see yourself, the way others see you and how they treat you as a result. To deal with the challenging situation of how people look at the hijab wearer differently, Nai'ma ${ }^{[32]}$ illustrated the following cases:

i) "Before I fully embraced Islam I had become quite friendly with one of the secretaries at my university and would often stop by her office for a laugh and a chat. However, when I started replacing my Afro-print headwraps with the hijab, a black one at that, she had great difficulty accepting it. When mentioning the change in me, she would often begin her sentences, "Oh, but you used to be so....vibrant, colourful, full of life, fun - these were all things that, for her, I was no longer. I tried in vain to explain my reasons for covering, but she just could not deal with it. She could not see past the exterior could not see the happy, confident me beneath the dark fabric."

ii) "My family used to say, "Since she started practising, she just let herself go. The abayah wasn't fitting her, she was fitting it...." All this had a very negative effect on her selfesteem and only made her feel resentful towards her hijab and abayah."

The challenge of family reaction of new Muslim choice on wearing hijab as mentioned in America is most likely the same case with those living in Britain. This can be best described on the study of American new Muslim women by Anway ${ }^{[33]}$ as she points out that the family is reasonably accepting their conversion until they take on hijab, at which point the attitude change. The change in their lives caused by choices of family members can be very destructive and cause broken relationships. The family can become confuse in how to relate to each other, and become upset and frustrated. She also states that the extreme change in dress is probably the hardest shift for the parents and relatives to accept when a daughter becomes Muslim. It seems an extreme statement about what they have chosen. In another study, Haifa ${ }^{[34]}(2006)$ states that wearing hijab for convert women, brings not only outside rejection and hostility but also strong family opposition. This could jeopardize family ties, which are already under strain as a result of conversion. To proof this arguments, some study cases among American new Muslim women illustrated below as quoted by Anway ${ }^{[35]}$ :

i) "I have worked out with my parents and other family members my choice to be Muslim. The main point of stress has been hijab or the Islamic dress. I think this is a constant reminder and embarrassment for them. If I were Muslim but did not cover, I think they could accept it more readily."

ii) "When I became Muslim, I had guidelines to express the beliefs I already had. Yet these changes were tough. It was hard to excuse myself from class or work to pray. When my clothing changed (covering my hair) I lost a lot of friends. I also had to explain to male friends that it was no longer appropriate for me to see them. I've also been shunned by a lot of relatives who tell my family I'll burn in hell!"

iii) "Due to hijab, there are a lot of prejudices out there. I definitely can't hold a very public "meeting people" job.

iv) "I have been denied jobs because of my hijab and have been otherwise openly discriminated against. Nonetheless, I am truly grateful for hijab. I feel honoured to represent Islam in such a powerful way as to be recognized as Muslim whenever I venture out."

The similar findings by Chuah ${ }^{[35]}$ (2008: 61) who studies Muslim coverts in Malaysia as he points out that in the survey, it was found that $65 \%$ of the fathers, $55 \%$ mothers $65 \%$ brothers and $65 \%$ sisters were against the family members' conversion into Islam and dress of Islam is part of the family's rejection.

i) My mother can now accept my conversion. Mother feels more comfortable with me. I was afraid when I started wearing the hijab. At last, I was determined. My sister once said, "You have the nerve to wear the hijab?" I said jokingly, "if you are going to do something, you might as well go all the way". If Islam tells us to pray or wear the hijab, we should just do it. Now, my family are more comfortable with my appearance and the change in my identity. My friends and the community around me responded awkwardly towards these changes, but I hardened my heart.

ii) I don't' told anybody since my father was in Miri at that time. My mother even didn't want me to tell him. I waited until my father came back home. Unfortunately my aunty had said it first to my father since she had seen me wearing hijab and told my father of my conversion to Islam. My father got angry at me and threaten to kill himself until I go back to my previous religion. 
iii) I was wearing hijab when I was at workplace. In order to avoid my father to get angry, I wore hijab not at home but at parking lot. My father dislike me wearing hijab. He eventually understood my situation now and he didn't care anymore of myself wearing hijab. He only reminds me to wear hijab when I went outing and not at home. I used to wear hijab once to three time when outing together with family.

iv) My mother got angry at me and said that there were many Muslim women outside there did not wearing hijab and look sexy more than the non-Muslim. She querried that you were Chinese and had just embraced to Islam, why your wife wore hijab?

These are just a few of the many changes women converts make as they develop and grow in their faith journey as a Muslim. The women wearing hijab express not only what a meaningful experience it is for them but also the frustration they sometimes have. They seem to help and support each other through the initial journey. They are accepting a set of practices that, although they may vary with cultural interpretations, are basically universal.

In the context of those living in the majority non-Muslim environment (Britain and America), they have to ask of bending their Western upbringing with that of their husband's culture, that of the Islamic practices, and that of the ummah that is their support group. All this they must do plus rebuilding relationships with their family of origin ${ }^{[36]}$. While those living in Muslim majority country (Malaysia), they are more easily bend with the Muslim culture from any other support groups of surroundings, friends and Muslim family-inlaws. In comparison, building religious identity for being an observant and practising Muslim is not more so difficult than those who living in non-Muslim majority country who are strangely been pushed to define themselves more clearly by wearing hijab.

\section{CONCLUSION}

In conclusion, the change of dress as prescribed by the Islamic teachings has been seen as a strange religious identity and not in line with the western lifestyles. The situation hardly difficult when the non-Muslim family of origin feel not comfortable with the change of dress that they used to wear before conversion to Islam. The gap of relationship seems too far when the family think that the new Muslim cannot mingle around with them anymore. In other words, wearing hijab create the big social gap among the family members who are no longer share the same religious affiliation. Therefore, wearing hijab is the endless struggle of their choices as similar to their initial struggle for choosing Islam as their new pathway of life.

\section{REFERENCES}

[1] Zebiri, K, British Muslim Converts: Choosing Alternative Lives, Oxford: Oneworld. 2008, p. 95.

[2] Jardim, G. L. and Vorster, J.M., Hijab and the construction of female religious identity, In die Skriflig, 36(2), 2003, 271-287. https://doi.org/10.4102/ids.v37i2.469

[3] [4] Ruby, T.F. (2006). Listening to the voices of hijab. Women's Studies International Forum, 29, 54-66. https://doi.org/10.1016/j.wsif.2005.10.006
[5] [6] Rafiqul-haqq, M. \& Newton, P., The place of women in pure Islam, Resource Centre for Muslim/Christian Dialog 1996, p.2 (available on internet: http://debate.domini.org/newton/women.html) date of access $25 / 08 / 2016$

[7] Ahmed, L., Women and gender in Islam: Historical roots of modern debate, New Haven, CT: Yale University Press, 1992.

[8] Tolaymat, L.D. \& and Moradi, B., U.S. Muslim women and body image: Links among objectification theory constructs and the hijab, Journal of Counseling Psychology, 58, 2011, p. 383-392. https://doi.org/10.1037/a0023461

[9] Prusher, I.R., Symbol of both oppression and freedom. Christian Science Monitor, 92(183), 2000, 8, November. (In EBSCOHost: Academic Search Premier, full display: http://www-sa.ebsco.com) date of access 25/08/2016.

[10] Ali, M., The Question of hijab: Suppession and Liberation. Islamic Academy for Scientific Research, Chicago: The Institute of Islamic Information an Education, 2001, p (available on internet: http://www.unn.ac.uk/societies/islamic/womn/hijab.htm. date of access 25/08/2016

[11] Na'ima, B. R., Fom M Sisters' Lips: A Unique Celebation of Muslim womanhood, London: Banam Books, 2006.

[12] Anway, C.L., Daughters of Another Path: Experiences of American Women Choosing Islam, Lincoln: Yawna Publication, 2002.

[13] Zebiri, K, British Muslim Converts: Choosing Alternative Lives, Oxford: Oneworld. 2008

[14] Al-Wazni, A. B., Muslim women in America and Hijab: A Study of Empowernment, Feminist Identity and Body Image, Social Work, Vol. 60 (4), 2015, p.325-333 https://doi.org/10.1093/sw/swv033

[15] Na'ima, B. R., Fom M Sisters' Lips: A Unique Celebation of Muslim womanhood, London: Banam Books, 2006, 186. Zebiri, K, British Muslim Converts: Choosing Alternative Lives, Oxford: Oneworld. 2008

[16] Zebiri, K, British Muslim Converts: Choosing Alternative Lives, Oxford: Oneworld. 2008, 106.

[17] Haddad, Y.Y., The post-9/11 "hijab" as icon, Sociology of Religion, 68(3), 2007, p. 253-267

https://doi.org/10.1093/socrel/68.3.253

[17] Maira, S., "Good" and "bad" Muslim citizens: Feminists, terrorist and U.S. orientalisms, Feminist Studies, 35, 2009, p. 631-656.

[18] Mernissi, F., The veil and the male elite: A Feminist interpretation of women's rights in Islam, New York: Basic Books, 1987, p.

[19] Mule, P \& Barthel, D. (1992). The return to the veil: Individual autonomy vs. social esteem. Sociological Forum, 7, 323-332 https://doi.org/10.1007/BF01125046

[20] Hatem, M., Egypt's middle class in crisis: The sexual division of labor, Middle East Journal, 42, 1988, p. 407-422.

[21] Mussap, A.J., Strength of faith and body image in Muslim and nonMuslim women, Mental Health, Religion \& Culture, 12(2), 2009, p.121-127. https://doi.org/10.1080/13674670802358190

[22] Ahmed, L., A quiet revolution: The veil's resurgence in from the Middle East to America. New haven, CT: Yale University Press, 2011.

[23] Haddad, Y.Y., The post-9/11 "hijab" as icon, Sociology of Religion, 68(3), 2007, p. 253-267

https://doi.org/10.1093/socrel/68.3.253

[24] Ali, S., Why here, why now? Young Muslim women wearing hijab, The Muslim World, 95, 2005, p. 515-530. https://doi.org/10.1111/j.1478-1913.2005.00109.x

[25] Bouma, G.D., \& Brace-Govan, J.,Gender and religious settlement: Families, hijabs and identity, Journal of Intercultural Studies, 21, 2000, 159-175. https://doi.org/10.1080/713678941

[26] Ruby, T.F. (2006). Listening to the voices of hijab. Women's Studies International Forum, 29, 54-66. 
https://doi.org/10.1016/j.wsif.2005.10.006

[27] Williams, R.H. \& Vashi, G., Hijab and American Muslim women: Creating the space for autonomous sleeves, Sociology of Religion, 68, 2007, p. 269-287.

https://doi.org/10.1093/socrel/68.3.269

[28] [29] [30] Zebiri, K, British Muslim Converts: Choosing Alternative Lives, Oxford: Oneworld. 2008, 37-38.

${ }^{[31]}{ }^{[32]}$ Na'ima, B. R., Fom M Sisters' Lips: A Unique Celebation of Muslim womanhood, London: Banam Books, 2006, pp.160-161.

[33] Anway, C.L., Daughters of Another Path: Experiences of American Women Choosing Islam, Lincoln: Yawna Publication, 2002, 73-79.

${ }^{\left[{ }^{34}\right]}$ Haifa, J., Female Conversion to Islam: The Sui Paradigm, In K.V. Nieuwlerk (Ed), Women Embracing Islam. Austin: Univesitiy of Texas Press, 2006.

[35] Chuah@ Osman Abdullah H.L dan Abd. Salam Muhammad Shkri, Muslim Converts in Malaysia: A Problem of Cultural Adjustment, International Islamic University, 2008.

[36] Anway, C.L., Daughters of Another Path: Experiences of American Women Choosing Islam, Lincoln: Yawna Publication, 2002, 91. 